Journal of Biotechnology and Strategic Health Research

Case Report / Olgu Sunumu

http://dergipark.org.tr/tr/pub/bshr

\title{
A Rare Case of Peritonitis Due to Pantoea agglomerans isolated from a Chronic Renal Failure Patient
}

\section{Kronik Böbrek Yetmezlikli Hastadan Nadir Bir Peritonit Etkeni Olarak İzole Edilen Pantoea agglomerans Olgusu}

\author{
(iD Tuğba Ayancı', (D) Radhwan Abdulrazzaq Khaleel Khaleel², (D) Peruze Aydın³, \\ (iD) $₫$ Tayfur Demiray ${ }^{1 *}$, (D) Özlem Aydemir ${ }^{1}$, (D) Savaş Sipahi ${ }^{5}$
}

\footnotetext{
${ }^{1}$ Sakarya University School of Medicine Department of Medical Microbiology

${ }^{2}$ Sakarya University Institute of Health Science Medical Microbiology

${ }^{3}$ Sakarya University Education and Research Hospital, Nephrology Clinic

${ }^{4}$ Sakarya University School of Medicine Department of Nephrology
}

ORCID ID: Tuğba Ayhanc1 https://orcid.org/000-0002-2115-6261

Radhwan Abdulrazzaq Khaleel Khaleel https://orcid.org/0000-0003-1317-6681, Peruze Aydin https://orcid.org/0000-0002-1960-4299

Tayfur Demiray https://orcid.org/0000-0003-1161-4684, Özlem Aydemir https://orcid.org/0000-0003-4533-6934

Savaş Sipahi https://orcid.org/0000-0002-4293-4341

^Sorumlu Yazar / Corresponding Author: Dr. Tayfur Demiray, e-posta / e-mail: tayfurdemiray@gmail.com

Geliş Tarihi / Received : 12-10-2021 Kabul Tarihi / Accepted: 05-11-2021 Yayın Tarihi / Online Published: 30-12-2021

Atıf Gösterimi/How to Cite: Ayancı T., Khaleel R.A, Aydın P., Demiray T., Aydemir Ö, SipahiS. A Rare Case of Peritonitis Due to Pantoea agglomerans isolated from a Chronic Renal Failure Patient, J Biotechnol and Strategic Health Res. 2021;5(3):253-257

Pantoea agglomerans, formerly known as Enterobacter agglomerans, is a facultative anaerobic Gram-negative bacillus and form yellow-pigmented colonies on culture media. It is an environmental microorganism, commonly found in soil, water, plants and food and can colonize in gastrointestinal system of humans. Although quite rare, P. agglomerans can cause wound infections, soft tissue or joint infections and nosocomial infections such as bacteriemia, pneumonia, septic arthritis, urinary tract infections, peritonitis, surgical wound infections and catheter related infections especially in immunocompromised patients. In this case report, we present a case of recurrent infections caused by $P$. agglomerans in a female chronic renal failure patient.

Keywords Pantoea agglomerans, chronic renal failure, peritonitis, antibacterial drug resistance

Özet

Önceden Enterobacter agglomerans olarak bilinen Pantoea agglomerans, fakültatif anaerobic, Gram negatif bir basildir ve kültür ortamında sarı pigmentli koloniler oluşturur. Toprakta, suda, bitkilerde ve yiyeceklerde yaygin olarak bulunan ve insanlarn gastrointestinal sisteminde kolonize olabilen çevresel bir mikroorganizmadır. Oldukça nadir olmakla birlikte, P. agglomerans yara enfeksiyonlarına, yumuşak doku veya eklem enfeksiyonlarına ve özellikle bağışıllğı baskılanmış hastalarda, bakteriyemi, pnömoni, septik artrit, idrar yolu enfeksiyonları, peritonit, cerrahi yara enfeksiyonlar ve kateterle ilgili enfeksiyonlar gibi hastane enfeksiyonlarma neden olabilir. Bu vaka raporunda, kronik böbrek yetmezliği olan bir kadin hastada tekrarlayan enfeksiyonlara neden olan P. agglomerans ile ilgili olguyu sunuyoruz. 


\section{INTRODUCTION}

Pantoea agglomerans is formerly known as Enterobacter agglomerans and is a member of Enterobacterales ${ }^{1}$. It is a facultative anaerobic Gram-negative bacillus, non-encapsulated, non-sporeforming and form evident yellow-pigmented colonies on routine culture media (Figure). It is a common environmental microorganism and can colonize in gastrointestinal system of humans. It is commonly found in soil, water, plants and food ${ }^{2,3}$. Infections due to Pantoea agglomerans are quite rare in healthy human (4). In certain cases, $P$. agglomerans can cause wound infections, soft tissue or joint infections by penetrating plant materials containing the bacterium. ${ }^{1,5}$ Although rare, nosocomial infections due to $P$. agglomerans are also reported such as bacteriemia, pneumonia, septic arthritis, urinary tract infections, peritonitis, surgical wound infections and catheter related infections especially in immunocompromised patients affecting all age groups including premature and elderly. ${ }^{5,6}$ It is worth mentioning that $P$. agglomerans survive at very low temperatures such as $+4{ }^{\circ} \mathrm{C}$ and can cause bacteriemia by contamination of intravenous fluids, total parenteral nutrition, the anesthetic agents, and blood products ${ }^{5}$ Beside its pathogenicity, some recent studies showed that scientist can benefit some properties of $P$. agglomerans like antibiotic production and immunopotentiator effect to prevent or treat infection diseases both in humans and animals. ${ }^{7}$. In this case report, we present a case of recurrent infections caused by $P$. agglomerans in a female chronic renal failure patient.

\section{CASE REPORT}

A 44-year-old adult female patient who she was on a treatment program of peritoneal dialysis due to chronic renal failure, was admitted to the nephrology clinic with the symptoms of nausea, diffuse abdominal pain and anuria. The dialysis solution was blurred. Vital signs were stable and recorded as follows; temperature $37,5^{\circ} \mathrm{C}$, heart rate 92/min and arterial blood pressure 94/56 mm-Hg. After medical examination, peritonitis was suspected and peritoneal fluid samples were collected. Number of inflamma- tory cells were very high and neutrophil dominance was detected by direct microscopic examination of the peritoneal fluid. The cell count per mm3 was too much which was out of the countable range. Vancomycin ( 1 gr per 72 $\mathrm{hr})$ and amikacin (100 mg/day) were administered via peritoneal catheter as an empirical antimicrobial treatment. The bacteriological culture of the peritoneal fluid yielded round, smooth and yellowish colonies on routine bacteriological agar plates (5\% sheep blood agar, eosin-methylene blue agar and chocolate agar plates) after 24 hours incubation at $37^{\circ} \mathrm{C}$ (Figure). Gram negative bacilli were detected with the microscopic examination of the colonies with gram-stained slide. The bacilli were later identified as Pantoea agglomerans with the VITEK ${ }^{\oplus}$ MS ( MALDI-TOF MS) (bioMérieux, Marcy l'Etoile, France). The antimicrobial susceptibility testing was carried out with the VITEK $^{\circledR} 2$ automated system automated system (bioMérieux, Marcy l'Etoile, France). The isolate was susceptible to piperacillin, tetracycline, trimethoprim/sulfamethoxazole, ciprofloxacin, levofloxacin, gentamicin, amikacin, ceftazidime, cefepime, imipenem and meropenem. According to the data from antimicrobial susceptibility testing, the patient's antibacterial treatment was revised. Vancomycin was discontinued and the patient was treated successfully only with amikacin since the patient was anuric. Approximately 14 months later, during the course of chronic renal failure, the patient again suffered nausea, diffuse abdominal pain and fever. Peritonitis was suspected and samples were collected. The cell count was 3050 cell $/ \mathrm{mm} 3$. Cephazolin ( 1 gr/day) and ceftazidime (1 gr/day) were administered via peritoneal catheter. P. agglomerans was detected by bacteriological tests and the isolate was fully susceptible to the antibacterial drugs which were tested. Within two days of antibacterial treatment, cell count was dramatically decreased to $299 \mathrm{cell} / \mathrm{mm} 3$. Patient recovered with the 10 days of ceftazidime treatment. However, 3 weeks later, the patient was admitted to the nephrology clinic again with probable diagnosis of peritonitis. The cell count was 3720 cell/mm3 and vancomycin ( 1 gr per $72 \mathrm{hr}$ ) together with amikacin $(100 \mathrm{mg} /$ day $)$ were prescribed to the patient. 
Once again, P. agglomerans was detected from the peritoneal fluid cultures. The isolate was susceptible to all antibiotics tested, except for ceftazidime and ceftriaxone. The patient was treated with antimicrobial treatment which was continued only amikacin for 14 days.

\section{DISCUSSION and CONCLUSION}

In modern medicine, there is an increase in interventional processes, increase in use of IV fluids, dialysis and blood products, and intensive care unit hospitalizations which may cause an increase in infections with rare opportunistic microorganisms and flora members which are not normally accepted as an agent of infection under normal circumstances. Pantoea agglomerans is an environmental microorganism and rarely causes infections after penetrating traumas especially with plants or soil which are contaminated with the bacterium. But the main concern should be nosocomial infections in immunocompromised patients of all age groups. In one study evaluating previous P. agglomerans infections in children, majority of the infections (81\%) occurred due to contaminated IV fluids, 13 $\%$ of the cases were due to penetrating trauma like thorn injury. Interestingly, there was a case of peritonitis due to contaminated dialysis solution in 2 years old female patient $^{1,8,9}$. Case reports of bacteriemia due to IV fluids contaminated with $P$. agglomerans are quite higher in number than other infections ${ }^{5}$. It is import to mention that Pantoea agglomerans is a member of Enterobacterales and resident of normal gastrointestinal flora of human. Meaning it can cause peritonitis or bacteriemia by disturbance to barriers of gastrointestinal system and translocation. In one case, peritonitis was observed after a rotavirus infection in an 18 -year-old male patient in which the cause of $P$. agglomerans peritonitis was linked to the translocation of the bacteria $^{10}$. In our case, the most probable way of the $P$. agglomerans peritonitis infections are the contaminated dialysis solutions, although it is a low probability but should be kept in mind that translocation can also cause peritonitis. Also in this case, chronic renal failure, peritoneal dialysis, catheterization are severe predisposing factors.
Most cases of Pantoea agglomerans infections respond to antimicrobial therapy quite well. In antimicrobial susceptibility tests, cephalosporins, aminoglycosides, carbapenems and quinolons are frequently determined as sensitive antimicrobials. In this presented case, all three P. agglomerans isolates were all found sensitive to the drugs that are tested except for the last isolates which was resistant to ceftazidime and ceftriaxone. When the $P$ agglomerans infection is a community acquired one, one can expect no resistance to the antimicrobials in concordance with the studies that evaluated wound and joint infections due to penetrating thorn traumas. In case of nosocomial infections, some virulence factors and drug resistance genes can be transferred by plasmids and other mobile elements of resistant bacteria $^{11}$. A remarkable ratio of carbapenem resistance in $P$. agglomerans isolates was provided in one study. Out of 14 documented P. agglomerans infections, three of the isolates were carbapenem resistant (21.4\%). Those patients had hospital-acquired infections and high resistance levels of the isolates can be explained by horizontal resistance gene transfer among pathogenic bacteria ${ }^{2}$.

In conclusion, $P$ agglomerans infections presented in scientific literature are growing in numbers as both community-acquired infections and nosocomial ones. Contaminated IV fluids, TPN solutions, dialysis solutions and blood products are main causes of infections with this microorganism and should be carefully inspected. Antimicrobial resistance in $P$. agglomerans may be a major concern due to increasing resistance through genetic resistance transfer mechanisms among Enterobacterales.

\section{Conflict of interes}

We attest that we have herein disclosed any and all financial or other relationships that could be construed as a conflict of interest and that all sources of financial support for this study have been disclosed and are indicated in the acknowledgments. All authors of this report declare no conflict of interest. 
J Biotechnol and Strategic Health Res. 2021;5(3):253-257

\section{Ethical Committee Approval}

Not needed

\section{Informed Consent}

Written informed consent was received from the patient.

We declare that the contents of this manuscript are our original work and have not been published, in whole or in part, prior to or simultaneous with our submission of the manuscript to the journal. The manuscript has been read and approved for submission by all authors. All persons listed as authors have contributed to preparing the manuscript and/ or that International Committee of Medical Journal Editors (IC-MJE) criteria for authorship have been met, and that no person(s) other than the authors listed have contributed significantly to its preparation. 
J Biotechnol and Strategic Health Res. 2021;5(3):253-257

\section{References}

1. Cruz AT, Cazacu AC, Allen CH. Pantoea agglomerans, a plant pathogen causing human disease. J Clin Microbiol. 2007;45(6):1989-1992. doi:10.1128/JCM.00632-07

2. Büyükcam A, Tuncer Ö, Gür D, et al. Clinical and microbiological characteristics of Pantoea agglomerans infection in children. J Infect Public Health. 2018;11(3):304-309. doi:10.1016/j.jiph.2017.07.020

3. Cheng A, Liu CY, Tsai HY, Hsu MS, Yang CJ, Huang YT, et al. Bacteremia caused by Pantoea agglomerans at a medical center in Taiwan, 2000-2010. J Microbiol Immunol Infect 2013;46(3):187-94.

4. Flores Popoca EO, Miranda García M, Romero Figueroa S, et al. Pantoea agglomerans in immunodeficient patients with different respiratory symptoms. ScientificWorldJournal. 2012;2012:156827. doi:10.1100/2012/156827

5. Kaur IP, Inkollu S, Prakash A, Gandhi H, Mughal MS, Du D. Pantoea agglomeransBacteremia: Is It Dangerous?. Case Rep Infect Dis. 2020;2020:7890305. Published 2020 Apr 3. doi:10.1155/2020/7890305

6. Shubov A, Jagannathan P, Chin-Hong PV. Pantoea agglomerans pneumonia in a heart-lung transplant recipient: case report and a review of an emerging pathogen in immunocompromised hosts. Transpl Infect Dis. 2011;13(5):536-539. doi:10.1111/j.13993062.2011.00630.x
7. Dutkiewicz J, Mackiewicz B, Lemieszek M K, Golec M, Milanowski J. Pantoea agglomerans: a mysterious bacterium of evil and good. Part IV. Beneficial effects. Ann Agric Environ Med. 2016;23(2):206-222. doi:10.5604/12321966.1203879.

8. Habsah H, Zeehaida M, Van Rostenberghe H, et al. An outbreak of Pantoea spp. in a neonatal intensive care unit secondary to contaminated parenteral nutrition. J Hosp Infect. 2005;61(3):213-218. doi:10.1016/j.jhin.2005.01.004

9. Matsaniotis NS, Syriopoulou VP, Theodoridou MC, Tzanetou KG, Mostrou GI. Enterobacter sepsis in infants and children due to contaminated intravenous fluids. Infect Control. 1984;5(10):471-477. doi:10.1017/s0195941700060872

10. Cicchetti R, Iacobini M, Midulla F, Papoff P, Mancuso M, Moretti C. Pantoea agglomerans sepsis after rotavirus gastroenteritis. Pediatr Infect Dis J. 2006;25(3):280-281. doi:10.1097/01.inf.0000202211.64017.c6

11. Manulis S, Barash I. Pantoea agglomerans pvs. gypsophilae and betae, recently evolved pathogens?. Mol Plant Pathol. 2003;4(5):307-314. doi:10.1046/j.13643703.2003.00178.x 